\title{
The Effect of Strategy Training on the Vocabulary Development of EFL Learners in Public High Schools of Iran
}

\author{
Seyyed Ali Ostovar-Namaghi \\ Shahrood University of Technology, Iran \\ Mehdi Rajaee \\ Islamic Azad University of Shahrood, Iran
}

\begin{abstract}
This study aimed at comparing the differential effect of vocabulary strategy training and traditional mode of presenting vocabulary. To this end, it statistically sampled sixty EFL language learners form an accessible population of 700 students. The subjects were then randomly assigned to the experimental and control group. Prior to treatment, they were given a vocabulary test to account for the initial differences between the two groups and subsequently after the treatment they were given a parallel test to account for the differential effect of strategy training and traditional mode of presenting words. Student $t$-test for independent and non-independent samples was used to analyze the data. The results showed that strategy training produced significantly higher results $(t=4.835, \mathrm{p}=0.0001<0.05)$. The study has useful implications for syllabus designers, teachers and researchers.
\end{abstract}

Index Terms - strategy training, vocabulary, teaching vocabulary

\section{INTRODUCTION}

Strategy training is one of the buzzwords of language teaching; nonetheless, it is rarely used in EFL contexts such as public high schools of Iran. The reason is that the syllabus is centrally imposed and as such determines what is to be taught. Moreover, uniform final exams and the university entrance exam (UEE) act as surveillance systems which guarantee that the teacher teaches nothing but the prescribed syllabus. Moreover, since teachers are always pressed for time, their main concern is covering the syllabus and preparing their students for the high stake UEE. This test ignores oral skills and focuses mainly on reading skills and vocabulary. In short success in this test depends on the breadth and depth of students' vocabulary. Despite the importance of vocabulary, this sub-skill is usually taught by bombarding students with long lists of de-contextualized bilingual words which are learned through repletion and memorization. This study aims at setting experimental conditions to compare the effect of vocabulary strategy training with that of traditional mode of presenting words and as such shed some lights on the feasibility of moving away from passive transmission of information towards strategy training in the language education system of Iran.

\section{REVIEW OF RELATED LITERATURE}

In what follows, first the researchers will present the most pertinent issues and options related to the importance of vocabulary development and how learners should tackle this task strategically. Then they will explain the shift away in language teaching towards learning strategies, the importance of learning strategies and the most pertinent empirical findings related to vocabulary strategy training will be reviewed to find out what has been done and as such find the gap in the knowledge base of vocabulary strategy training.

\section{A. Vocabulary Development}

Traditionally, syllabus designers marginalized the role of vocabulary. That is, textbooks were very specific about other aspects of language including reading, speaking and grammar but vocabulary had a peripheral role (Richards \& Renandya, 2002, p. 255). Thus it can be said that curriculum has been derailed since as telegraphic speech clearly shows, it is quite possible to create a message without any resort to function words but it is totally impossible to create a message without content words. This tradition of marginalizing vocabulary is in sharp contrast with Wilkins's (1972) historical comment "while without grammar very little can be conveyed, without vocabulary nothing can be conveyed" (p. 111) because vocabulary knowledge is instrumental in reading comprehension (Read, 2000; Qian, 2002). It is shown that knowledge of vocabulary is closely related to reading comprehension and Vermeer (2001) suggests vocabulary can be used as one of the best predictor of language proficiency at school. The results of a survey of L2 learners by Leki and Carson (1994) have also revealed that university students consider insufficient knowledge of vocabulary items as the most important factor impeding their progress in writing tasks. 
Sokmen (1997) presents strategies for independent vocabulary learning by stating that it is "not possible for students to learn all the vocabulary they need in the classroom" (p. 225). To move students towards independence, it is essential that teachers take time and teach the process and the strategies of vocabulary development. Learning vocabulary in a foreign language is a five-step process: (a) having sources for encountering new words, (b) getting a clear image, either visual or auditory or both, of the forms of the new words, (c) learning the meaning of the words, (d) making a strong memory connection between the forms and the meanings of the words, and (e) using the words (Hamzah et al., 2009, citing Brown and Payne, 1994).

As for strategy development, Schmitt (2000) presents discovery and consolidation strategies to differentiate the strategies they use to clarify the meaning of unknown words from those they use which aim at consolidating the meaning of words they have already encountered. Cunningsworth (1995) considers teachers' role in vocabulary strategy training as "a powerful approach", which sensitizes learners to the systematic nature of vocabulary, encourages optimal use of dictionary, and motivates learners to reflect on their vocabulary learning techniques (p. 38).

\section{B. Learning Strategies and Strategy Training}

Brown (2007) stated that in 1970s teachers and researchers found that no single research finding and no single method of language teaching would guarantee universal success. They realized that irrespective of the method they follow some learners were successful. Along the same line, Rubin (1975) and stern (1975) described good learners in terms of personal traits, strategy use and learning styles; therefore, interests in learning strategies began with the publication of papers collectively known as the "good language learner" studies (Cohen \& Weaver, 1998). Compared with other interested researchers, Chamot (1987), Cohen (1998) and Oxford (1990) have scrutinized language learning strategies more vigorously.

Scholars motivated by the desire to familiarize learners with language learning strategies have offered several definitions of strategies:

- the thought processes learners use in apprehending, learning and retaining new information (O'Malley \& Chamot, 1990, p. 1).

- the actual techniques learners employ in systematically tacking input and output (Brown, 2007, p. 132).

- the behaviors learners employ in order to learn and regulate the learning of another language (Wenden, 1987).

- the actions they take to facilitate and catalyze learning and making it self-directed in terms of transfer objective (Oxford, 1990, p. 8).

- the mental and communicative procedures learners use in order to learn and use language (Nunan, 2001).

- a goal-oriented tactic used by a player in skilled performance (Williams \& Burden (1997).

For nearly two decades researchers focused on analyzing related works to classify learning strategies. Different studies have identified different ways of categorizing strategies (Oxford, 1990). For instance O'Malley and Chamot (1990) classified strategies in three broad categories: cognitive, metacognitive, and socio-affective, each of which includes lots of sub-strategies. On the other hand, Oxford (1990a) developed a strategy system that contains six sets of L2 learning behaviors: affective (e.g., anxiety reduction through laughter and meditation); social (e.g., asking questions); metacognitive (e.g., planning for language tasks); memory-related (e.g., grouping and imagery); general cognitive (e.g., summarizing and practicing); and compensatory (e.g., guessing meanings form the context). According to O'Malley and Chamot (1990), learners use these strategies together in a synergistic mode, assuming that no single strategy can guarantee vocabulary development. Anderson (2002b) believes that "developing metacognitive awareness may also lead to the development of stronger cognitive skills" (p. 1).

Learning words without knowing how to do it is just like driving a car without knowing how to drive. Thus prior to learning, it is essential that learners develop a large repertoire of vocabulary learning strategies. Many scholars have underlined the importance of vocabulary learning strategies because they lead to:

- greater awareness of what you are doing (Nuuan,2001)

- active self-directed involvement in learning and greater self-confidence (Oxford, 1990)

- learner autonomy since they have guiding tools to be used both inside and outside of the class (Oxford \& Scarcella, 1994)

- increased retention of the new vocabulary and increased availability of these items for active use (Gu \& Johnson, 1996)

- active control over learning and more responsibility for studies ((Nation, 200

- learner autonomy, independence, and self-direction" (Oxford \& Nyikos, 1989)

- better recall due to independence in choosing which words to learn (Ranalli, 2003).

- a significant increase in the number of words (Nation, 2001)

- significant reduction in vocabulary teaching time since strategies are readily teachable (Oxford \& Nyikos, 1989).

Taking the importance vocabulary learning strategies into account, strategy training should be an inseparable part of vocabulary instruction. In effect, it is the strategy repertoire the students use that determines the breadth and depth of learners' vocabulary. Thus it is essential that language teaches move away from teaching towards strategy training because empirical findings clearly show that: 
- there is a positive correlation between vocabulary learning strategies and vocabulary size on the one hand and reading comprehension on the other $(\mathrm{Gu}, 1999)$.

- the use of vocabulary learning strategies has a direct effect on vocabulary and an indirect effect on reading comprehension(Curtis,1987).

- compared with reading comprehension, vocabulary learning strategies better predicts vocabulary size (Cusen, 2005).

- metacognitive strategy training positively affects vocabulary development in EFL contexts (Eslami Rasekh \& Ranjbary, 2003).

- vocabulary learning strategies significantly increases learners' vocabulary size (Kafipour, 2009).

According to Schmitt and Schmitt (1995) an effective teaching plan trains learners in a myriad of vocabulary learning strategies. Along these lines, this study aims at developing EFL learners' repertoire of vocabulary learning strategies through strategy training and testing the efficiency of this approach relative to the traditional mode under controlled experimental conditions. More specifically, this study was conducted to find out whether vocabulary strategy training and the traditional mode of presenting vocabulary produce the same effect or differential effects. To answer this question systematically, the researchers will test the following hypotheses:

1. There is a significant difference in performance between the vocabulary strategy training group and the group taught via the traditional mode prior to experimental treatment.

2. There is a significant difference in the performance of experimental group prior and after vocabulary strategy training.

3. There is no significant difference in performance between the vocabulary strategy training group and the group taught via the traditional mode after the experimental treatment.

\section{RESEARCH METHOD}

\section{A. Research Context}

This study was conducted in public high schools of Iran. In this context, teaching and learning are greatly overshadowed by the university entrance exam (UEE) which ignores oral skills and focuses mainly on reading comprehension, grammar and vocabulary. This is a norm-referenced test which aims at screening students, especially in terms of their knowledge of vocabulary. High performance on this test is contingent upon the breadth and depth of vocabulary. Under such conditions, vocabulary development is the main teaching and learning activity.

\section{B. Subjects}

The accessible population of this study was 700 students studying in grade one high schools of Gonabad, a major city in the Southern Khorasan. To statistically sample the subjects, the researchers followed cluster sampling, i.e. from the total high schools of Gonabad, the researchers randomly selected one high school and from that high school, they randomly selected two classes of thirty students. Finally, they randomly assigned the students into experimental and control groups. Thus all in all, the study sampled sixty high school male students in grade one aging between 13 and 15 years old. It is worth noting that the target population will be all students studying in grade one high schools of Iran since condition are uniform throughout the country. The design chosen for this study is Randomized Subjects, Pretest Posttest Control Group Design.

\section{Procedure}

Prior to treatment, a pre-test was administered to identify any probable differences in performance between the control and experimental groups. During the treatment, the control group was taught using the traditional book-based approach by covering the exercises and activities in the textbook irrespective of vocabulary learning strategies; conversely, the experimental group was presented with different types of social, memory, cognitive and metacognitive strategies. After differential treatment both groups were given a post-test so as to identify the differential effect of treatment on the two groups.

\section{Data Collection and Analysis}

To collect the research data, the researchers used two parallel forms of teacher-made vocabulary tests. To ensure reliability of the instruments, the tests were administered to a similar group in another high school. Thus reliability was ensured through correlating two-maximally similar tests (Bachman, 1991) and the coefficient of correlation was found to be 0.84 . To ensure content validity of the tests, they were given to two teachers to ensure the one-to-one correspondence between test content and textbook content. Both tests consisted of 40 multiple-choice items of vocabulary. One was used to account for the entry behavior, i.e. students' knowledge of vocabulary prior to the test and while the other was used to check the exit behavior, i.e. the differential effect of different modes of presenting vocabulary.

Since the researchers aimed at comparing two groups and the groups were taken independently from the population, student t-test for independent samples was used to analyze the data. However, to compare pretest posttest performance, t-test for non-independent samples was used. The data were analyzed using the SPSS. 


\section{RESULTS}

The study aimed at testing the following null hypotheses:

1. There is no significant difference in performance between the vocabulary strategy training group and the group taught via the traditional mode prior to experimental treatment.

2. There is no significant difference in the performance of experimental group prior and after vocabulary strategy training.

3. There is no significant difference in performance between the vocabulary strategy training group and the group taught via the traditional mode after the experimental treatment.

To test the first hypothesis, first the descriptive statistics related to the two groups were calculated. The results are shown in table 1 .

TABLE 1.

DESCRIPTIVE STATISTICS: PRE- TEST

\begin{tabular}{|l|l|l|l|l|}
\hline Group & N & Mean & Std. Deviation & Std. Error Mean \\
\hline control & 30 & 34.6333 & 2.77282 & .50624 \\
\hline experimental & 30 & 34.8333 & 2.56076 & .46753 \\
\hline
\end{tabular}

Although the descriptive statistics show that the two groups performed almost equally, they are not dependable since they show sample characteristics, i.e. statistics. To estimate parameters or population characteristics, the data were analyzed using t-test for independent samples. The results are shown in table 2.

TABLE 2.

INDEPENDENT SAMPLES TEST

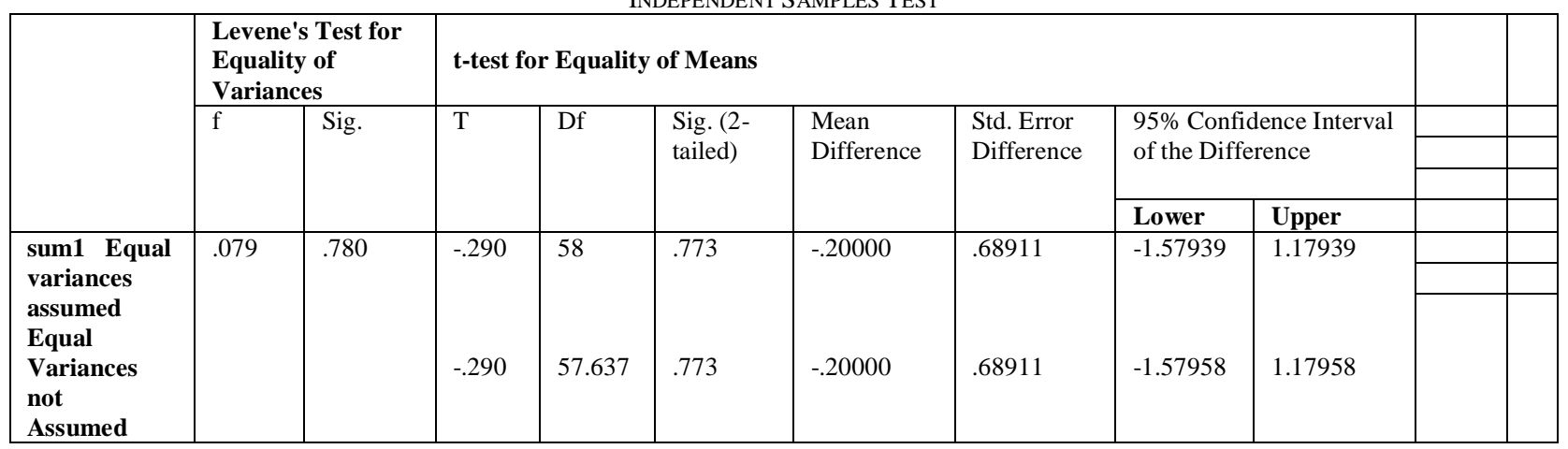

As table 2 clearly shows, the variance of the two groups is not significantly different $((\mathrm{F}=0.079, \mathrm{p}=0.773>0.05)$. Moreover, the mean scores related to the two groups are not significantly different $(t=0.290, p=0.773>0.05)$. Thus the first hypothesis is verified, i.e. there is no significant difference between the mean scores of two groups.

To test the second hypothesis, i.e. there is no significant difference in the performance of experimental group prior and after vocabulary strategy training, the researchers used matched t-test, or t-test for non-independent samples. The performance of the experimental group on the writing post-test is shown in table 3.

TABLE 3.

DESCRIPTIVE STATISTICS: EXPERIMENTAL GROUP

\begin{tabular}{|c|c|c|c|c|c|}
\hline & & Mean & $\mathrm{N}$ & Std. Deviation & Std. Error Mean \\
\hline \multirow[t]{2}{*}{ Pair 1} & sum1 & 34.6333 & 30 & 2.77282 & .50624 \\
\hline & sum2 & 38.4000 & 30 & 1.27577 & 23292 \\
\hline
\end{tabular}

The researchers then used matched t-test, or paired samples test, to go beyond sample characteristics and estimate population characteristics. The results are shown in table 4.

TABLE 4.

PAIRED SAMPLES TEST

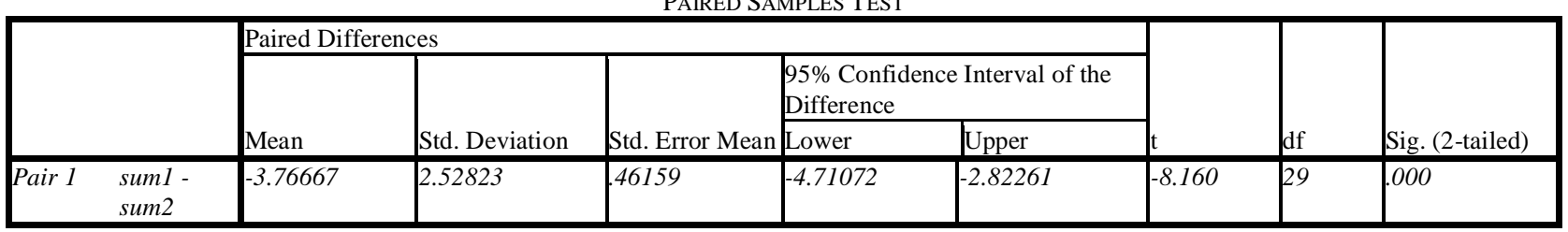

As Tables 4 clearly shows, there is a significant difference between experimental group's mean before and after treatment $(\mathrm{P}=0.001)$. Thus the chance explanation, i.e. the null hypothesis is rejected in favor of the research hypothesis. In other words, the vocabulary training strategies had a significant effect on vocabulary learning. This difference 
becomes more evident if there is a basis for comparison, i.e. the control group's performance in the post test. To see the effect of placebo, i.e. traditional mode of presenting words, see table 5.

TABLE 5.

CONTROL GROUP: PRE-TEST POST-TEST

\begin{tabular}{|c|c|c|c|c|c|c|c|c|c|}
\hline & & \multicolumn{5}{|c|}{ Paired Differences } & & \multirow[b]{3}{*}{ df } & \multirow{3}{*}{$\begin{array}{l}\text { Sig. }(2 \\
\text { tailed) }\end{array}$} \\
\hline & & \multirow[b]{2}{*}{ Mean } & \multirow[b]{2}{*}{ Std. Deviation } & \multirow[b]{2}{*}{ Std. Error Mean } & \multicolumn{2}{|c|}{$\begin{array}{l}\text { 95\% Confidence Interval of the } \\
\text { Difference }\end{array}$} & & & \\
\hline & & & & & Lower & Upper & $\mathrm{t}$ & & \\
\hline Pair 1 & sum1 - sum2 & -.06667 & 2.43443 & .44446 & -.97570 & .84236 & -.150 & 29 & .882 \\
\hline
\end{tabular}

As it is shown in tables 5, there is no significant difference between control group's mean in pre-test and posttest. $(\mathrm{P}>0.05)$. Thus, it can be concluded that strategy training is more effective than the traditional mode of presenting words.

To test the third null hypothesis, i.e. strategy training and traditional mode of teaching vocabulary have the same effect, we analyzed the performance of the two group on the post test. Tables 6 and 7 show the descriptive statistics and the results of independent sample t-test.

TABLE 6.

GROUP STATISTICS

\begin{tabular}{|ll|l|l|l|l|}
\hline \multicolumn{2}{|c|}{ Group } & $\mathrm{N}$ & Mean & Std. Deviation & Std. Error Mean \\
\hline sum2 & experimental & 30 & 38.4000 & 1.27577 & .23292 \\
& Control & 30 & 34.9000 & 3.75408 & .68540 \\
\hline
\end{tabular}

TABLE 7.

INDEPENDENT SAMPLES TEST: EXPERIMENTAL AND CONTROL GROUP AFTER TREATMENT

\begin{tabular}{|c|c|c|c|c|c|c|c|c|c|c|}
\hline & \multicolumn{2}{|c|}{$\begin{array}{l}\text { Levine's Test for } \\
\text { Equality of Variances }\end{array}$} & \multicolumn{7}{|c|}{ t-test for Equality of Means } \\
\hline & & \multirow[b]{2}{*}{$\mathrm{F}$} & \multirow[b]{2}{*}{ Sig. } & \multirow[b]{2}{*}{$\mathrm{t}$} & \multirow[b]{2}{*}{ Df } & \multirow{2}{*}{$\begin{array}{l}\text { Sig. (2- } \\
\text { tailed) }\end{array}$} & \multirow{2}{*}{$\begin{array}{l}\text { Mean } \\
\text { Difference }\end{array}$} & \multirow{2}{*}{$\begin{array}{l}\text { Std. Error } \\
\text { Difference }\end{array}$} & \multicolumn{2}{|c|}{$\begin{array}{l}95 \% \text { Confidence } \\
\text { Interval of the } \\
\text { Difference }\end{array}$} \\
\hline & & & & & & & & & Lower & Upper \\
\hline sum2 & $\begin{array}{l}\text { Equal variances assumed } \\
\text { Equal variances not } \\
\text { assumed }\end{array}$ & 12.007 & .001 & $\begin{array}{l}4.835 \\
4.835\end{array}$ & $\begin{array}{l}58 \\
35.610\end{array}$ & $\begin{array}{l}.000 \\
.000\end{array}$ & $\begin{array}{l}3.50000 \\
3.50000\end{array}$ & $\begin{array}{l}.72389 \\
.72389\end{array}$ & $\begin{array}{l}2.05097 \\
2.03132\end{array}$ & $\begin{array}{l}4.94903 \\
4.96868\end{array}$ \\
\hline
\end{tabular}

As tables 6 and 7 clearly show, the variance of the two groups is significantly different $(\mathrm{P}<0.05)$. In addition these two groups differ significantly in their mean scores $(p<0.05)$. The results of the t-test better show the significance of this difference. Therefore, it can be concluded that vocabulary training strategies is significantly more effective than the traditional mode of presenting words.

\section{CONCLUSION AND IMPLICATIONS}

The results clearly showed that the group which received vocabulary strategy training significantly outperformed the group which learned vocabulary through traditional activities prescribed by the textbook. Since the study is trueexperimental in nature, the results can be generalized to other similar situations, especially to all other public high schools of Iran because as we mentioned in the introduction, the UEE has created uniform conditions and make teachers follow a uniform approach. Taking the results of study into account, it is recommended that:

- syllabus designers build strategy training into the nationally prescribed syllabus;

- syllabus designers do away with traditional exercises and reduce the volume of the material covered so that teachers have enough time to exercise their professional knowledge and experience to teach empowering vocabulary learning strategies;

- teachers move away from the transmission model of education, which aims at covering the syllabus towards strategy training which aims at training independent learners;

- teachers plan ahead and develop materials which aim at familiarizing students with empowering strategies and emancipate them from prevalent limiting strategies;

- and interested researchers test the efficiency of this approach in college preparatory courses in public and private sector.

\section{REFERENCES}

[1] Anderson, N. J. (2002b). Using telescopes, microscopes, and kaleidoscopes to put metacongnition into perspective. TESOL Matters, 12 (4), 2002.

[2] Bachman, L. (1990). Fundamental considerations in language testing. Oxford: Oxford University Press. 
[3] Brown, H. D. (2007). Principles of language learning and teaching ( $5^{\text {th }}$ ed.). White Plains, NY: Longman.

[4] Brown, C. \& Payne, M. E. (1994). Five essential steps of processes in vocabulary learning. Paper presented at the TESOL Convention, Baltimore Celce-Murcia, M.

[5] Chamot, A. (1987). The learning strategies of ESL students. In A. Wenden \& J. Rubin (Eds.), Learner strategies in language learning (pp. 71-84). Cambridge: Cambridge University Press.

[6] Cohen, A. D. (1998). Strategies in learning and using a second language. London: Longman.

[7] Cohen, A. D., Weaver, S. F., \& Li, T. (1998). The impact of strategic-based instruction on speaking a foreign language. In A. Cohen (Ed.), Strategies in learning and using a second language (pp. 107-156). London: Longman.

[8] Cunningsworth, A. (1995). Choosing your Coursebook. UK: Heinemann English Language Teaching

[9] Daoud, A.M. \& Celce-Murcia, M. (1979). Selecting and Evaluating Textbooks. In M. Celce-Murcia \& L. Mc-Intosh (Eds.), Teaching English as a Second or Foreign Language (pp. 302-307). New York: Newbury House.

[10] Curtis, M. E. (1987). Vocabulary Testing and Instruction. In M.G. McKeown \& M. E. Curtis (Eds.), The nature of vocabulary acquisition. Hillside, NJ: Lawrence Erlbaum.

[11] Cusen, G. (2005). Investigating vocabulary learning strategies: A case study of Romanian undergraduates with a professional interest in learning English as a foreign language. Unpublished $\mathrm{PhD}$ thesis, Lancester University, Lancester, United Kingdom.

[12] Eslami Rasekh, Z., \& Ranjbary, R. (2003). Metacognitive strategy training for vocabulary learning. TESL-EJ, 7(2), 1-12.

[13] Gu, Y. (1999). Vocabulary learning strategies and English language outcomes. Unpublished PhD thesis, University of Hong Kong, Hong Kong.

[14] Gu, Y., \& Johnson, R. K. (1996). Vocabulary learning strategies and language earning outcomes. Language Learning, 46(4), 643-679.

[15] Hamzah, M.S., Kafipour, R., and Abdullah, S. K. (2009). Vocabulary Learning Strategies of Iranian Undergraduate EFL Students and its Relation to their Vocabulary Size. European Journal of Social Sciences. Volume 11(1), pp. 39- 50.

[16] Kafipour, R. (2009). Vocabulary learning strategies of Iranian undergraduate EFL students and its relation to their vocabulary size. European Journal of Social Sciences, 11(1), 39-50.

[17] Leki, I., \& Carson, J. G. (1994). Students perception of English for academic purpose writing instruction writing need across the disciplines. TESOL Quarterly, 28, 81-101.

[18] Nation, P. (2000). Learning vocabulary in lexical sets: dangers and guidelines. TESOL Journal, 2, 6-10.

[19] Nunan, D. (2001). Second language teaching and learning. Boston:Heinle \& Heinle Publishers.

[20] O'malley, J. M., \& Chamot, A. U. (1990). Learning strategies in second language acquisition. Cambridge: Cambridge University Press.

[21] Oxford, R. (1990). Language learning strategies: What every teacher should know. Boston: Newbury House.

[22] Oxford, R. \& Scarcella, R.C. (1994). Second language vocabulary learning among adults: State of the art in vocabulary instruction. System, 22(2), 231-243.

[23] Oxford, R., \& Nyikos, M. (1989). Variables affecting choice of language learning strategies by university students. The Modern Language Journal, 79(3), 291-300.

[24] Qian, D. (2002). Investigating the relationship between vocabulary knowledge and academic reading performance: An assessment perspective. Language Learning, 52(3), 513-536.

[25] Ranalli, J. (2003). The treatment of key vocabulary learning strategies in current ELT course books: Repetition, resource use, recording. Unpublished MA thesis. University of Birmingham, Birmingham, United Kingdom.

[26] Read, J. (2000). Assessing vocabulary. Cambridge: Cambridge University Press.

[27] Richards, J. C., \& Renandya, W. A. (Eds.). (2002). Methodology in language teaching: An anthology of current practice. Cambridge, UK: Cambridge University Press.

[28] Rubin, J. (1975). What the "good language learner" can teach us. TESOL Quarterly, 9, 41-51.

[29] Sokmen, A. (1997). Current trends in teaching second language vocabulary. In N. Schmitt \& M. McCarthy (Eds.), Vocabulary: Description, acquisition and pedagogy (pp. 237-257). Cambridge: Cambridge University Press.

[30] Schmitt, N. (2000). Vocabulary in language teaching. New York: Cambridge University Press.

[31] Schmitt, N., \& Schmitt, D. (1995). Vocabulary notebooks: Theoretical underpinnings and practical suggestions. ELT Journal, 49, 133-243.

[32] Stern, H. (1975). What can we learn from the good language learner? Canadian Modern Language Review, 34, 304-318.

[33] Vermeer, A. (2001). Breadth and depth of vocabulary in relation to L1/L2 acquisition and frequency of input. Applied Psycholinguistics, 22, 217-234.

[34] Wenden, A. L. (1987). Incorporating learner training in the classroom. In A. L. Wenden, \& J. Rubin (Eds.), Learner strategies in language learning (pp. 31-42). Englewood Cliffs, NJ: Prentice-Hall.

[35] Wilkins, D. A. (1972). Linguistics in language teaching. London: Edward Arnold Ltd.

[36] Williams, M., \& Burden, R. (1997). Psychology for language teachers. Cambridge University Press.

Seyyed Ali Ostovar-Namaghi is an associate professor of TEFL at Shahrood University of Technology. His chief research interest is language teacher knowledge. He has published in a number of leading peer-reviewed journals including: The Reading Matrix (California), Teacher Education Quarterly (California), The Qualitative Report (Florida), The Asian EFL Journal (South Korea), Journal of Language Teaching and Research (Finland), Theory and Practice in Language Teaching (Finland), and Sino-Us Foreign Language (Ohaio). Presently he runs courses in EAP at Shahrood University of Technology.

Mehdi Rejaee is an MA student at Azad University of Shahrood, Science and Research Branch. Currently he teaches English in public high schools of Gonabad. 